\title{
Technological Gap in Adoption of Recommended Practices of Loose Flowers in Tamil Nadu, India
}

\author{
J. I. Jergin ${ }^{1}$, Rexlin Selvin ${ }^{1 *}$, K. Mahandra Kumar ${ }^{1}$ and A. Beaulah ${ }^{2}$ \\ ${ }^{1}$ Department of Agricultural Extension \& Rural Sociology, Agricultural College \& Research \\ Institute-TNAU, Madurai-625 104, India \\ ${ }^{2}$ Department of Horticulture, Agricultural College \& Research Institute-TNAU, \\ Madurai-625 104, India \\ *Corresponding author
}

\section{A B S T R A C T}

\section{Keywords}

Adoption,

Chrysanthemum,

Technological gap,

Tuberose

Article Info

Accepted:

15 April 2020

Available Online:

10 May 2020
The present study was conducted on technological gap in adoption of recommended practices of loose flowers in Tamil Nadu. The study was carried out in Krishnagiri, Salem and Tiruvannamalai districts of Tamil Nadu. Six villages (2 villages from each district) were selected based on the criteria of maximum area under rose, Chrysanthemum and Tuberose cultivation. 40 farmers were randomly chosen and thus 120 respondents from three districts has been chosen. The findings revealed that, among the various recommended practices the maximum gap were observed in recommended varieties of tube rose ( $100.00 \%)$ chrysanthemum- MDU 1(95.00\%), bud capping and yellow trap $(75.00 \%)$, control measure of powdery mildew $(75.00 \%)$ and black spot disease in rose. Further, lack of awareness about the recommended varieties, lack of availability of skilled labours and high cost in adopting the practices were expressed as reasons for technological gap in loose flower cultivation.

\section{Introduction}

India is bestowed with diverse agro-climatic and ecological conditions which are favourable to grow all types of commercially important flowers generally found in different parts of the world. It also enjoys the best climate in selected pockets for floriculture during winter months. India is an enviable position to become a leader in the world floricultural trade because of the prevailing congenial location, overall favourable climate of liberalization and globalization and also specific incentives by the government and floricultural development. According to Shivkumar (2009) the soil and climatic conditions of South India are ideally suited for floriculture. Flowers have a language of their own. 
They convey different feelings and thoughts including that of love. Most Hindu ladies adore their hair style with flower i.e., Gajra and veni and it is one of the important floral ornament which will and grace to their beauty opined by Yogesh Nagar (2018). Tamil Nadu is known for flower cultivation since ages. A large number of flowers are produced in the state on commercial scale. The flower cultivation is traditionally concentrated in certain pockets throughout the state. In Tamil $\mathrm{Nadu}$, loose flowers are produced in an area of about 34227.98 hectares with the production of 4,29,922.83 MT (jasmine, chrysanthemum, marigold, rose, crossandra and nerium) per annum. In the present study an attempt was made to find out the technological gap of loose flower cultivation in Tamil Nadu.

\section{Materials and Methods}

The study was carried out in Denkanikottai, Omalur and Kilpennathur taluks of Krishnagiri, Salem and Tiruvannamalai districts of Tamil Nadu where the maximum area was under rose, Chrysanthemum and Tuberose cultivation. Six villages( two villages from each taluk) viz., Urigam, Bairamangalam, Theevattipatti, Chikkampatti, Iyenkulam and Kilpennathur were selected based on the criteria of maximum area under Rose, Chrysanthemum and Tuberose cultivation. By considering the time constraints, it was decided to choose 40 respondents from the selected districts.

A list of farmers was obtained from the village level extension workers (AHO) from the selected villages of the selected districts from which 40 farmers were randomly chosen and thus 120 respondents from three districts having highest area under rose, chrysanthemum and tuberose has been chosen. A pre-tested interview schedule was used to collect the data through personal interview method. The data collected were tabulated and analyzed by using suitable statistical measures.

The technological gap was operationally defined as the difference between the recommendation and actual adoption of improved loose flower cultivation practices by the loose flower growers. For ascertaining the technology adoption gap about loose flower cultivation practices, 19 practices for rose and chrysanthemum crop and 12 practices for tube rose which was recommended by Horticulture Scientists, Tamil Nadu Agricultural University were considered. The responses were collected from individual respondents on important practices for each crop. To measure the variable, 0 score was given for non-adoption and 1 score was given for adoption. The scores of all the practices were added together and considered as an individual score. On the basis of the score obtained for technologies adopted, the technological gap index (TGI) for each practice was worked out with the help of technological gap index developed by Biradar (2012)

$T G I=\frac{R-A}{R} X 100$

Where $\mathrm{R}=$ Total Recommended practices score (Maximum adoption score)

$\mathrm{A}=$ Actually adopted practices score by the individual loose flower grower

\section{Results and Discussion}

\section{Crop production technologies}

The data presented in table 1 revealed that 70.00 per cent of technological gap was noticed in adoption of recommended Edward rose variety. The reason might be that rose growers felt that the variety was a low yielding variety. 
62.50 percent of technological gap was observed in recommended button rose variety, followed by application of micro nutrients $(62.50 \%)$.It was confirmed that micronutrient deficiency is not a significant and vital problem in the study area and that is the reason of having much technological gap on this practice.

Further, 50 per cent of technological gap was observed in adoption of recommended Andhra red rose variety, followed by application of bio fertilizers $(50.00 \%)$ and height of planting material( $37.50 \%) .25$ per cent of gap was observed in practices like planting material, application of growth regulators and application of NPK dosage. Most of them in study area believed that the recommended quantity of NPK fertilizer was sufficient to get the expected yield and that is the reason of having low technological gap on this practice.

While only 12.50 per cent of technological gap was observed $i$ in recommended time of split dosage of FYM. The reason for low gap might be availability of FYM in the village itself. There was no technological gap in recommended spacing $(0.00 \%)$. Rose growers felt that the recommended spacing would increase the yield which would fetch remunerative price and moreover rose cultivation with recommended spacing alone eligible for subsidy by the Government. This might be the reason for no technological gap on this practice. This finding derives support from Sridevi (2014)

\section{Intercultural operations}

The technological gap was wide in recommended intercultural practices like yellow trap (75.00\%), bud capping (75.00 $\%)$, Deshooting and disbudding $(70.00 \%)$ and wild shoot removal $(50.00 \%)$. Since these practices involved awareness and skill on the part of labourers, which normally they won't have, might be the reasons for high to medium level of technological gap. Only 25 per cent of technological gap was noticed in bending technique practice. Since this practice has direct impact on yield and income to the rose growers might be the reason for low gap. This finding derives support from Giritharan (2018)

\section{Crop protection measures}

75 per cent of technological gap was observed in recommended control measure of powdery mildew, followed by black spot disease $(62.50$ per cent). The reason might be due to the cost involved in adopting the practices and the non-availability of labours. 40 per cent of the gap was found in control measure of white grab, followed by rose chaffer beetle $(25 \%)$.

The common tendency prevailing among the rose growers was spraying pesticides leads to a better control of pest effectively. This might be due to the reason for low gap. No technological gap $(0.00 \%)$ i.e., cent per cent of adoption was seen in control measure of physiological disorder of bend neck. The reason might be the frequent occurrence of symptom in the study area.

\section{Crop production technologies}

The data presented in table 2 revealed that 95.00 per cent of technological gap in adoption of recommended MDU 1 variety followed by Red Gold variety $(90.00 \%), \mathrm{CO}$ 2 variety $(62.50 \%)$ and application of bio fertilizers $(62.50 \%)$.Lack of awareness and complexity of technologies might be the reasons for high technological gap.

About 50 per cent of gap was observed in application of NPK dosage, followed by time of split dosage of application (42.50\%), recommended $\mathrm{CO} 1$ variety $(37.50 \%)$, 
application of micronutrients (32.50) and application of growth regulators $(12.50 \%)$ respectively. There was no technological gap ie, cent per cent of adoption was observed in recommended practices like seed rate, spacing and propagation. Chrysanthemum growers felt that recommended propagation method increases the yield in Chrysanthemum when compared to other traditional method. This might be the reason for $0.00 \%$ technological gap.

\section{Intercultural operations}

About 50 per cent of technological gap was found in the recommended netting practice, followed by pinching $(15.00 \%)$ and disbudding $(10.00 \%)$. No gap was seen in desuckering practice. This might be due to the fact that all the chrysanthemum growers were aware of de-suckering, since it is a traditional one.

\section{Crop protection measures}

75 per cent of technological gap was observed in recommended control measure of red spider mite, followed by leaf minor (70 \%), Thrips, aphids, leaf eating caterpillars $(42.50$ $\%)$, leaf $\operatorname{spot}(15 \%)$, and root rot $(12.50 \%)$. The low level of technological gap might be due to high infestation of pests and diseases in study area. This finding was in accordance with the finding of Vasanthi (2015).

\section{Crop production technologies}

Cent per cent of technological gap was noticed in recommended varieties like Rajat Rehka, Khahikuchi single, Hydrabad single, Pune single, Calcutta single, Hydrabad double and pearl double. This might be due to the reason that the tuberose growers were not aware about the recommended varieties. 87 per cent of technological gap was identified in recommended dosage of micronutrient application followed by recommended variety Calcutta single (70\%), Vaibhav (70\%), Phule Rajani (62.50\%), Swarna Rekha(62.50\%), Mexican single(50\%) and Suvasini (50\%). About 50 per cent of technological gap was observed in Basal fertilizer application, followed by application of top dressing of fertilizers (40\%) and growth regulators (25.00 $\%)$.

No gap was found in recommended practices like Prajwal variety $(0.00 \%)$, method of propagation $(0.00 \%)$ and spacing $(0.00 \%)$. Spacing is an important practice which decides the number of plants per acre in turn the yield level. Hence tube rose growers might be trained about the recommended spacing and its advantages. This might be the reason for cent per cent of adoption.

\section{Technologies pertaining to harvest}

No gap was found that the recommended practices like stage of harvest $(0.00 \%)$ and time of harvest $(0.00 \%)$. All the respondents had done harvesting at the appropriate time. This might be due to the fact that all the respondents were aware of that timely harvesting would improve the flower quality.

\section{Crop protection measures}

The data presented in table 3 revealed that 37.50 per cent of technological gap in control measure of aphids, followed by root knot nematode (30.00 per cent). The low level of technological gap was that tuberose growers might have perceived that these infestations would affect the yield and quality of flowers. No gap was seen in control measure of thrips. The reason for 100 per cent adoption might be high occurrence of the symptoms. The findings are in line with the findings as reported by Chandra et. al. (1990) 
Table.1 Distribution of respondents according to their technological gap in rose cultivation

\begin{tabular}{|c|c|c|c|}
\hline $\begin{array}{l}\text { Sl. } \\
\text { No. }\end{array}$ & Recommended technologies & $\begin{array}{l}\text { Obtained } \\
\text { response of } \\
\text { respondents }\end{array}$ & $\begin{array}{l}\text { Technological } \\
\text { gap Index } \\
(\%)\end{array}$ \\
\hline $\mathbf{I}$ & Crop Production Technologies & & $(n=40)$ \\
\hline 1. & \multicolumn{2}{|l|}{ Varieties } & \\
\hline a. & Edward rose & 12 & 70.00 \\
\hline b. & Andhra red rose & 20 & 50.00 \\
\hline c. & Button rose & 15 & 62.50 \\
\hline 2. & Planting material (cuttings) & 30 & 25.00 \\
\hline 3. & Height of Planting Material(40-70 cm length) & 25 & 37.50 \\
\hline 4. & $\operatorname{Spacing}(2.0 \times 1.0 \mathrm{~m})$ & 40 & 00.00 \\
\hline 5. & $\begin{array}{l}\text { Time of spilt dosage application of } \\
\text { FYM(October and July) }\end{array}$ & 35 & 12.50 \\
\hline 6. & $\begin{array}{l}\text { Application of NPK dosage(FYM } 10 \mathrm{~kg}+ \\
6: 12: 12 \mathrm{~g} \mathrm{NPK})\end{array}$ & 30 & 25.00 \\
\hline 7. & $\begin{array}{l}\text { Application of micronutrients( } 20 \mathrm{~g} \mathrm{MnSO} 4+ \\
15 \mathrm{~g} \mathrm{MgSO} 4+10 \mathrm{~g} \mathrm{FeSO} 4+5 \mathrm{~g} \mathrm{~B})\end{array}$ & 15 & 62.50 \\
\hline 8. & $\begin{array}{l}\text { Application of bio -fertilizers }(2 \mathrm{~kg} \\
\text { Azospirillum and Phospho bacteria mixed with } \\
100 \mathrm{~g} \text { FYM in pit weekly) }\end{array}$ & 20 & 50.00 \\
\hline 9. & $\begin{array}{l}\text { Growth regulators: } 250 \text { ppm of GA3 ( } 30 \text { days } \\
\text { after pruning) }\end{array}$ & 30 & 25.00 \\
\hline II & Inter cultural operations & & \\
\hline 10. & Bending technique & 30 & 25.00 \\
\hline 11. & Wild shoot removal & 20 & 50.00 \\
\hline 12. & Deshooting and disbudding & 12 & 70.00 \\
\hline 13. & Yellow trap & 10 & 75.00 \\
\hline 14. & Bud capping & 10 & 75.00 \\
\hline \multirow[t]{2}{*}{ III } & Crop protection measures & & \\
\hline & Pest & & \\
\hline 15. & $\begin{array}{l}\text { Rose chaffer beetle: Quinalphos 25EC@2mi/lit } \\
\text { +Light trap to attract Holotrichia and } \\
\text { Anomalaspp }\end{array}$ & 30 & 25.00 \\
\hline \multirow[t]{2}{*}{16.} & White grub: Phosalone 35EC@ 2ml/lit & 24 & 40.00 \\
\hline & Diseases & & \\
\hline 17. & Black spot disease: Carbendazim 1g/lit & 15 & 62.50 \\
\hline \multirow[t]{2}{*}{18.} & Powdery mildew: Wettable sulphur $2 \mathrm{~g} / \mathrm{lit}$ & 10 & 75.00 \\
\hline & Physiological disorders & & \\
\hline 19. & Bent Neck & 40 & 00.00 \\
\hline
\end{tabular}


Table.2 Distribution of respondents according to their technological gap in Chrysanthemum cultivation

\begin{tabular}{|c|c|c|c|}
\hline $\begin{array}{l}\text { Sl. } \\
\text { No. }\end{array}$ & Recommended technologies & $\begin{array}{l}\text { Obtained } \\
\text { response of } \\
\text { respondents }\end{array}$ & $\begin{array}{c}\text { Technological } \\
\text { gap Index } \\
(\%)\end{array}$ \\
\hline & Crop Production Technologies & & $(n=40)$ \\
\hline 1. & Varieties & & \\
\hline a. & $\mathrm{CO} 1$ & 25 & 37.50 \\
\hline b. & $\mathrm{CO} 2$ & 15 & 62.50 \\
\hline c. & MDU 1 & 2 & 95.00 \\
\hline e. & Red Gold & 4 & 90.00 \\
\hline 2. & Seed rate $(1,11,000$ Plants/ha $)$ & 40 & 0.00 \\
\hline 3. & Spacing $\left(15 \times 15 \mathrm{~cm}\left(45\right.\right.$ plants $\left./ \mathrm{m}^{2}\right)$ & 40 & 0.00 \\
\hline 4. & $\begin{array}{l}\text { Time of spilt dosage application of FYM(October and } \\
\text { July) }\end{array}$ & 23 & 42.50 \\
\hline 5. & $\begin{array}{l}\text { Application of NPK dosage( } 25 \text { t FYM + 125:120:25 } \\
\mathrm{kg} / \mathrm{ha} \text { ) }\end{array}$ & 20 & 50.00 \\
\hline 6. & $\begin{array}{l}\text { Application of micronutrients } \\
\text { (Foliar spray of } \mathrm{ZnSO}_{4} 0.25 \%+\mathrm{MgSO}_{4} 0.5 \% \text { ) }\end{array}$ & 27 & 32.50 \\
\hline 7. & $\begin{array}{l}\text { Application of bio -fertilizers }(2 \mathrm{~kg} \text { Azospirillum and } \\
\text { Phosphobacteria mixed with } 100 \mathrm{~g} \text { FYM in pit weekly) }\end{array}$ & 15 & 62.50 \\
\hline 8. & Time of pruning(Remove the side suckers periodically) & 40 & 0.00 \\
\hline 9. & $\begin{array}{l}\text { Growth regulators: }\left(\mathrm{GA}_{3} 100-400 \mathrm{ppm}-3 \text { DAP and }\right. \\
\text { 6DAP - increases stem length) }\end{array}$ & 35 & 12.50 \\
\hline 10. & Propagation(Suckers and rooting of cutting ) & 40 & 0.00 \\
\hline II & Inter cultural operations & & \\
\hline 11 & Pinch.ing & 34 & 15.00 \\
\hline 12. & Netting & 20 & 50.00 \\
\hline 13. & Disbudding & 36 & 10.00 \\
\hline 14. & De-suckering & 40 & 0.00 \\
\hline \multirow[t]{2}{*}{ III } & Crop protection measures & & \\
\hline & Pest & & \\
\hline 15. & $\begin{array}{l}\text { Thrips, aphids, leaf eating caterpillars: Acetamiprid @ } \\
0.3 \mathrm{~g} / \text { lit }\end{array}$ & 23 & 42.50 \\
\hline 16. & Leaf miner: Imidacloprid @ 0.5 ml/l & 12 & 70.00 \\
\hline \multirow[t]{2}{*}{17.} & Red spider mite : Abamectin 1.9 EC @ 0.5 ml/l & 10 & 75.00 \\
\hline & Diseases & & \\
\hline 18. & Root rot : Copper oxychloride $2.5 \mathrm{~g} / \mathrm{lit}$ & 35 & 12.50 \\
\hline 19. & Leaf spot : Mancozeb @ $2.5 \mathrm{~g} / 1$ & 34 & 15.00 \\
\hline
\end{tabular}


Table.3 Distribution of respondents according to their technological gap in Tuberose cultivation

\begin{tabular}{|c|c|c|c|}
\hline $\begin{array}{l}\text { Sl. } \\
\text { No. }\end{array}$ & Recommended technologies & $\begin{array}{l}\text { Obtained } \\
\text { response of } \\
\text { respondents }\end{array}$ & $\begin{array}{l}\text { Technological } \\
\text { gap Index } \\
(\%)\end{array}$ \\
\hline 1. & \multicolumn{2}{|l|}{ Varieties } & $(n=40)$ \\
\hline a. & Calcutta Single & 12 & 70.00 \\
\hline b. & Mexican Single & 20 & 50.00 \\
\hline c. & Phule Rajani & 15 & 62.50 \\
\hline d. & Prajwal & 40 & 0.00 \\
\hline e. & $\begin{array}{l}\text { Rajat Rekha, Khahikuchi Single, Hyderabad } \\
\text { Single, Pune Single, Calcutta Double, } \\
\text { Hyderabad Double, Pearl Double }\end{array}$ & 0 & 100.00 \\
\hline f. & Swarna Rekha & 15 & 62.50 \\
\hline g. & Suvasini & 20 & 50.00 \\
\hline f. & Vaibhav & 12 & 70.00 \\
\hline 2 & $\begin{array}{l}\text { Method of propagation(Bulbs/1,12,000 } \\
\text { bulbs/ha) }\end{array}$ & 40 & 0.00 \\
\hline 3. & Spacing $(45 \times 20 \mathrm{~cm})$ & 40 & 0.00 \\
\hline 4. & Basal fertilizer application(FYM : 25 t/ha) & 20 & 50.00 \\
\hline 5. & $\begin{array}{l}\text { Application of top dressing of fertilizers(N: } \\
\text { P: K : 200:200:200 kg/ha) }\end{array}$ & 24 & 40.00 \\
\hline 6. & $\begin{array}{l}\text { Micronutrients (Foliar spray of } \mathrm{ZnSO}_{4} 0.5 \% \\
+\mathrm{FeSO}_{4} 0.2 \%+\text { Boric acid } 0.1 \% \text { ) }\end{array}$ & 5 & 87.50 \\
\hline \multirow[t]{2}{*}{7.} & $\begin{array}{l}\text { Growth regulators (Foliar application of } \mathrm{GA}_{3} \\
\text { at } 50 \text { to } 100 \mathrm{ppm} \text { thrice at } 40,55 \text { and } 60 \text { days } \\
\text { after planting.) }\end{array}$ & 30 & 25.00 \\
\hline & Technologies pertaining to harvest & & \\
\hline 8. & Stage of harvest(florets start to open) & 40 & 0.00 \\
\hline \multirow[t]{2}{*}{9.} & $\begin{array}{l}\text { Time of harvest(individual florets are } \\
\text { plucked during early morning hours before } 8 \\
\text { am daily) }\end{array}$ & 40 & 0.00 \\
\hline & Plant Protection Measures & & \\
\hline 10. & $\begin{array}{l}\text { Thrips (Spray Dimethoate @ } 1.5 \mathrm{ml} / \text { lit or } \\
\text { Fipronil } 5 \% \text { SC @ } 1.5 \mathrm{ml} / \text { ) }\end{array}$ & 40 & 0.00 \\
\hline 11. & $\begin{array}{l}\text { Aphids (Spary Dimethoate @ } 1.5 \mathrm{ml} / \text { lit or } \\
\text { Imidacloprid @ 1.5ml/l) }\end{array}$ & 25 & 37.50 \\
\hline 12. & $\begin{array}{l}\text { Root knot nematode (Apply Carbofuran } 3 \mathrm{G} \\
\text { @ } 1 \mathrm{~g} / \text { plant near the root zone and irrigate } \\
\text { Immediately) }\end{array}$ & 30 & 25.00 \\
\hline
\end{tabular}


The findings revealed that among the various recommended practices the maximum gap were observed in recommended varieties of tube rose ( $100.00 \%$ ) chrysanthemum- MDU $1(95.00 \%)$, bud capping and yellow trap $(75.00 \%)$ control measure of powdery mildew $(75.00 \%)$ and black spot disease in rose.

Further, lack of awareness about the recommended varieties, lack of availability of skilled labours and high cost in adopting the practices were expressed as reasons for technological gap in loose flower cultivation. Proper trainings, demonstrations, exhibitions and meetings may be conducted to the farmers to get awareness about the complexity of the recommended practices and thereby adoption level can be increased.

\section{References}

Biradar G.S., (2012). A study on Technological Gap in Adoption of Improved Chilli Cultivation Practices in
Yadagir and Raichur Districts of Karnataka. M.Sc. (Agri.) Thesis, Univ. Agric. Sci., Raichur.

Chandra, Hiranand and Sharma J.P. (1990). Knowledge, Adoption \& constraints Analysis of Potato Technology. IJEE, 26 (1\& 2) : 94-98

Giritharan, N.(2018). A Multi-Dimensional Analysis on Flower Cultivation in Krishnagiri District. Unpub. M.Sc. (Ag.), Thesis, AC\&RI, TNAU, Madurai Shivkumar K. P. (2009) Kisan World, 61-62.

Sridevi, K. (2014). Technology Adoption and Marketing Behaviour of Coffee Growers - A Diagnostic Study. Unpub. Ph.D. Thesis, AC\&RI, TNAU, Madurai.

Vasanthi, R. (2015). An analytical study on jasmine cultivation in Madurai district of Tamil Nadu. Unpub. Ph.D. Thesis, Thesis, AC\&RI, TNAU, Madurai.

Yogesh Nagar (2018). A Study on Marketing Behaviour of flower growers in Ujjain District, Ph.D. Thesis. College of Agriculture, Gwalior.

\section{How to cite this article:}

Jergin, J. I., Rexlin Selvin, K. Mahandra Kumar and Beaulah, A. 2020. Technological Gap in Adoption of Recommended Practices of Loose Flowers in Tamil Nadu, India. Int.J.Curr.Microbiol.App.Sci. 9(05): 1806-1813. doi: https://doi.org/10.20546/ijcmas.2020.905.205 